\title{
The Education of Academic Librarians
}

\section{John Budd}

Progress in education for academic librarianship has been hindered by an adherence to training, rather than to graduate education. While recommendations from within and outside the profession have urged the upgrading of education, developments have been slow in coming. All of librarianship should share a common core curriculum, but the complexities of academic librarianship (and the environment in which academic libraries operate) point to subject and functional specializations necessary for some personnel. Education for academic librarianship should prepare students for the roles they are to assume within the community of higher education.

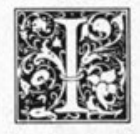

n 1887, when Melvil Dewey established at Columbia University the first school designed to educate librarians, the course of education for librarians was set, and, while there has been some progress in curricular matters in the last one hundred years, the effects of that early effort are with us today. Dewey's program emphasized the practical skills that he envisioned as essential to the efficient operation of a library. Debate over the most desirable proportional mixture of theory and practice rages yet; some individuals bemoan the dearth of the one whenever they see what they consider to be too much of the other. Dewey's philosophy of education as apprenticeship has shown itself to be enduring, though, and that philosophy may be the single greatest hindrance to progress in the area of educating academic librarians. ${ }^{1}$

Examination of education for academic librarianship implies an inherent difference between it and librarianship in other environments. There are certainly differences among the clientele served by public libraries, school libraries, special libraries, and academic libraries. These differences do not constitute an artificial distinction; it is not just a matter of providing information for different groups of people. The nature of the collections of these libraries is different, as are the kinds and depth of services and the manner in which they are provided. This phenomenon is directly related to the differing purposes of the varying environments. There is something about the college or university that sets it apart from other segments of society. Alfred North Whitehead posits that the mere provision of information is not sufficient reason for the existence of the university (he sees the proliferation of printed books as negating such a mission) and that "the justification for a university is that it preserves the connection between knowledge and the zest of life, by uniting the young and the old in the imaginative consideration of learning. ${ }^{\prime 2}$

The academic library does not simply operate in this milieu, it is a vital and integral component of the process of education. Because of this, the academic librarian must be engaged in that process as an active participant. This is not to say that the activities of the librarian are identical to those of other members of the academic community, but the librarian, in order to function as a facilitator of the imaginative quest for knowledge, must work in concert with other members of the community toward fulfilling the university's purpose. If this distinction between academic

John Budd is a doctoral student in the School of Library Science, at the University of North Carolina-Chapel Hill. The author would like to thank Professors Barbara Moran and Lester Asheim for their comments and assistance. 
and some other types of librarianship (which is not meant to assume superiority) is accepted, then it becomes clear that the education of academic librarians should be equally distinctive. Beverly Toy notes that

programs for training academic librarians should be significantly different from those of other librarians. The M.L.S. should include a common core of training, but for academic librarians it will tend to be the beginning level, as advanced work in librarianship and/or programs in scholarly disciplines require more than can be accomplished through the M.L.S. degree. $^{3}$

A brief look at the history of education for librarianship reveals that in 1923 Charles C. Williamson stated that professional librarians should receive broad, general education in full college courses plus at least one year's graduate study in a library school. ${ }^{4}$ Williamson's report has had considerable impact on the development of library education, though the development has not been rapid and is, in fact, still occurring. In 1924, the Association of American Universities (AAU) recommended that library education be at the graduate level and that this graduate education be two years in length, but the AAU's recommendation went essentially unheeded. ${ }^{5}$ Ralph Munn, in his report of 1936, stated that librarians at universities, great public, and some special libraries need a broad, general educational background, proficiency in at least one foreign language, technical knowledge, a scholarly attitude, and two years of library school training. ${ }^{6}$ Munn takes the attitude that academic librarians are partners in the scholarly process and should be trained as scholars. Louis Round Wilson shared this attitude. In 1949 Wilson saw the one-year master's degree as a superficial change from the bachelor's degree, but he was encouraged by some changes in the content of curricula and some new (at the time) doctoral programs.

This debate over the length of library education has neither died nor abated since 1949. Ralph Conant, in his sometimesmaligned report, recommends that library schools provide opportunities for specialization, including interdepartmental and interdisciplinary study, within a two-year curriculum. ${ }^{8}$ Edward G. Holley discusses the extended library school program and offers examples of some institutions that have made the decision to extend their programs beyond one year. ${ }^{9}$ While there are some schools with extended programs, these are in a distinct minority and there are no indications that employers display a preference for graduates from these programs. (The exception to this is the recommendation of the Office of Personnel Management that only those individuals with two years of graduate study be hired at the GS-9 level.) ${ }^{10}$

Peter Drucker discusses the amount of education required for those in public service institutions (including libraries), which, he claims, may not be as extensive as is popularly thought. He states that

many individuals in the professions are overtrained for the responsibilities assigned to them. This is partly due to the bureaucratic nature of the public service institutions they serve in, but it also may be related to an exaggerated notion of the training needed to enter the profession. ${ }^{11}$

Drucker's statement betrays some ignorance about academic librarianship (and some aspects of librarianship in general). First, he does not seem to realize that the first exposure many individuals receive to the discipline of library science is at the graduate level. This will be discussed in greater detail later in this paper. Drucker also ignores the fact that the academic library assists in the fulfillment of the institution's educational goals, thus, the library is not concerned merely with mechanical processes. To borrow from Pierce Butler, the operation of the library involves a science, which deals with the properties of the materials; a technology, which is involved with the processes used in exploiting the materials; and a humanity, which involves "the motives, reasons, purposes, or ends for which the science had been accumulated and the technology invented." 12

If librarians are indeed to share in the purpose of the college or university and if they are to join in the community of scholars, then the education of academic librarians should at least approximate that 
of their colleagues. Though a number of undergraduate library science programs remain, many existing as minor fields in schools of education, the first year of the master's program is essentially introductory. This is a necessity because of the number of individuals who enter library schools from other fields. Therefore, the specialization needed to prepare one to begin to take a place in the community of scholars is, perforce, minimally achieved at best in the one-year program. A similar thought may have motivated one respondent in Conant's study to say, "We cannot count on the master's degree in librarianship as an assurance of an applicant's ability to meet the needs of the academic library; moreover, lack of the MLS is not a barrier to effective academic librarianship. ${ }^{\prime 13}$ Another academic librarian interviewed in the course of the Conant study indicated that "the interdisciplinary nature of academic librarianship cannot be satisfied within the existing limits of professional education in library schools." 14

Indictments of the past and present state of education for academic librarianship by Robert Muller and Lewis A. Kenney indicate that there is dissatisfaction in many sectors with educational practices. ${ }^{15}$ No single culprit can be blamed for the dissatisfaction or the apparent failure to meet the needs of the profession and of academe. The tradition of training begun in the last century has developed strong roots, and there has been effort at change by the profession's associations or the schools themselves. The question remains as to what route library education should take in order best to prepare the schools' graduates for placement in institutions of higher education. What do students need to know? What type of preparation best suits the mission of higher education? What is the breadth and depth of education needed for academic librarians? What role should academic librarians assume on college and university campuses?

Librarianship has relied for years on a prerequisite knowledge and the ability to adapt that knowledge to the workings of the profession. There has also been an assumption that the academic librarian has certain qualities, be they learned or in- bred. Such so-called assets as a love of books are no longer sufficient (if they ever were) for academic librarians because librarianship encompasses more than artifacts. The view of librarians as researchers or teachers is not to be ignored, but it is sometimes tied to a notion that librarians should directly emulate teaching faculty in the narrowness of subject scope to be studied. There is no doubt that the ability to conduct fruitful research in a particular subject area is beneficial (assuming that the area of librarianship is also a valid subject area), but it must be accompanied by something more. The academic librarian must have an intimate knowledge of the purpose of the college or university and a willingness to participate in achieving that purpose.

Edward G. Holley elaborates on this particular aspect of the orientation of the academic librarian. He says that such a person needs

some background in the history and development of higher education ... an appreciation for the history of scholarship and learning and the way knowledge is obtained in various disciplines... [and] the ability to evaluate research findings. ${ }^{16}$

The above comment includes the recognition that the academic library and librarianship are products of scholarship and the community of scholars who are producers and consumers of that scholarship. In this way, this branch of the profession is derivative; it depends upon the parent institution for its existence, and it functions as an integral part of the institution. Because the library supports all other components of the institution, the librarian must know something of the objectives and practices of the other components. The symbiotic relationship should be reflected in the knowledge of the librarian, so the education of academic librarians should aim to provide the requisite knowledge.

While the above described breadth of education is ideal, it is not always found in practice. H. William Axford (who, unfortunately, fails to avoid overgeneralization and assumes a uniform paucity in library education and in most librarians) observes that the library school does not always 
achieve the noble end. He writes of the deficiency of the educational process,

which simply does not engender in students the attitudes necessary to feel at home with the traditional values of the academy, particularly its canons of scholarship. In spite of the rhetoric to the contrary, and the significant programs in professional education achieved since the Williamson report, library education today is still more vocational than professional in the classical meaning of the term. ${ }^{17}$

The recognition of this weakness calls into question the library school's ability to provide education befitting partners in the academic community. There is implicit in such a view the belief that education in a library school is not sufficient for an individual to function in an academic library. This involves the concept of specialization in libraries, about which more will be said later.

In light of the above, an examination of library education must begin with the most fundamental of its premises. It has been recognized for a number of years that all of librarianship shares a basis of intellectual content, regardless of the individual student's eventual career objective to carry out those functions and processes central to all libraries. In 1954 a workshop was held at the University of Chicago's Graduate Library School on the subject of a core of educational content. ${ }^{18}$ The librarians and the educators in attendance recognized the need for such a core. Some years later Jesse Shera expressed the belief that a core of knowledge is essential and that it "must be streamlined to emphasize the elements that are fundamental to the practice of all librarianship whatever the specialization. ${ }^{\prime 19}$ Lester Asheim went into more detail in describing that which is necessary and vital to all librarianship. He claims that education should include a mix of

first, understanding of the underlying discipline; then, introduction to the mechanisms derived from it that lead to present practices; finally, analysis of how the skills and attitudes emerging from the discipline and the operational devices are applied in practice. ${ }^{20}$

Asheim's perceptive remarks can hold true for much of education in general. $\mathrm{He}$ describes educational components that apply, not only to library education, but also to education in many disciplines. Asheim also touches on some of the reasons why the community of higher education has been reluctant to accept library education as it currently exists and to accept holders of the M.L.S. degree into that community. While the master's degree in library science attempts to include all of the elements Asheim sets forth (in rhetoric, at any rate), other disciplines tend to incorporate the introduction to the discipline and its mechanics into the undergraduate curriculum. The M.L.S., particularly the one-year M.L.S., must attempt to introduce students to the discipline and to teach also the analysis of the theory and practice of librarianship. Thus it becomes clearer that the single year is inadequate to provide the depth of education needed.

The types of educational preparation needed by academic librarians depend to a great extent on the nature of the library itself. Just as the library is an amalgamation of many functions, it must serve the needs of many academic disciplines. The librarians on a given campus are likely to have (in fact may be hired because of diverse educational backgrounds. Robert B. Downs states:

Like the teaching faculty, librarianship is becoming increasingly a career for specialists, and our requirements are exceedingly diverse. In the future, college university librarians will undoubtedly be called upon to have academic preparation as thorough and as advanced as their colleagues in other fields. ${ }^{21}$

Shera also recognizes the inevitability of the need for specialization, but, at the same time, he reiterates the importance of the core as the basis for all library education.

The value of specialization and the utility of specialized knowledge is not to be minimized, but unless it is held together by the cohesive force of a generalized concept of librarianship that underlies all that the librarian does, the inevitable result is fragmentation of the profession to the point at which all standards of performance and all criteria of excellence will be lost. ${ }^{22}$

If service in the academic library is to be 
provided by specialists, what type of specialization should be prevalent? Many individuals see a need in libraries for professionals with additional graduate education in another subject field. The reliance upon graduate education in library (and information) science and in a cognate subject area (a list of which would be lengthy) has been evident for some years. This preference probably hearkens back to the days of librarian as scholar and may be a sort of reaction against Dewey's emphasis on practical training.

Librarians saw the need for advanced subject education as so necessary to the performance on the job that allowance for the attainment of additional graduate degrees was included in the "Standards for College Libraries" of 1959. One section of the "Standards" states:

It follows that librarians-in line with the established policies at their institutions-should be expected to do graduate work in such areas as would contribute to their effectiveness in their respective positions. In some instances such a program of study might well lead to a second or third Master's degree rather than to a Ph.D. degree. $^{23}$

This statement is not present in the 1975 revision of the standards. At about the time of the revision, the Association of College and Research Libraries (ACRL) was articulating support for the M.L.S. degree as a terminal degree and as the appropriate education for the professional librarian. If the ACRL dictum were universally accepted, the faculty status issue, for one, would have a resolution. The fact that the M.L.S. is not unconditionally acceptable to many college and university administrators and faculties with regard to faculty status reveals that the level of education librarians see as sufficient is not thought of outside the profession as equivalent to that of the teaching faculty. Moreover, ACRL neglects to address the kind and depth of education that the academic librarian should have in order to contribute to the educational purpose of the academic community.

William Moffett takes the issue of educational attainment a step further by suggesting that libraries could benefit from hiring individuals with subject Ph.D.s, in- dividuals who could bring to the job teaching experience, who could work on the curriculum, and who could fuel the faculty status fire. ${ }^{24}$ Joe Rader provides a dissenting voice in the midst of calls for more advanced degrees. He writes,

To say to librarians that, to get a job in the first place or to achieve career advancement within the profession, one must have a subject master's is to say that the library degree, ipso facto, is of little value. Apparently to be treated as a real professional, one must obtain a real advanced degree. $^{25}$

Rader's comments do address the question of the legitimacy of the library school degree on the college or university campus. They do not, however, address the question of the role of the academic librarian, a question that has yet to be answered satisfactorily or conclusively.

The education of academic librarians is also somewhat dependent on the functions that individuals perform within the library. This, again, is not a revelation. In 1949 Lawrence Clark Powell wrote, "To function properly then, the academic library must be staffed by a corps of professional librarians with varying, not equal, amounts of graduate educationmanagers, collectors, processors, interpreters, and curators." 26 The amounts of graduate education need not vary greatly, but the areas could certainly be quite divergent. Margaret Myers observes the possible expansion of the functional specializations of librarians as libraries evolve in conjunction with societal and technological progression. ${ }^{27}$ Patricia Battin also recognizes the various functions within the library, particularly the research library, and has definite suggestions with regard to hiring practices. She says that employees should

hire the talent they need and hope that the MLS will follow, or else . . . set up, as large corporations have done, [research libraries'] own educational programs to provide the specialized training we perceive as necessary. If the choice lies between credentials and talent, I think we must opt for the talent. ${ }^{28}$

Battin's suggestion is apparently contrary to Rader's defense of the library degree and to the statements of those believ- 
ers in a core curriculum for students. By negating the need for the M.L.S. as a credential for library service, she implies a like shift in the educational attainment of the prospective employee of the research library. Though it is unstated, one can assume that Battin would look first to education that would complement the functional need to be filled and, only when that is satisfied, to the M.L.S. She enumerates the personal qualities that the librarian in the research library should possess:

\section{A first-rate mind with problem-solving abili-} ties.

2. A solid undergraduate preparation in any of a variety of disciplines.

3. Concrete evidence of managerial abilities.

4. An intellectual commitment to research librarianship. ${ }^{29}$

While graduate education is not mentioned in the list, it is clear that Battin envisions the research library staffed with many individuals whose education and training match the need she sees as inherent in the research library.

Which of the needed specializations can be supplied by library schools? The nature of libraries is such that several individuals perform duties that are somewhat distinctive, if not discrete, while sharing the nebulous goal of service to a particular community. This is compounded in academic libraries by the magnitude of information, the physical and intellectual diversity of collections, the sophistication and wideranging interests of the academic community, and, in some instances, the technology required to meet information needs. In the larger libraries, the librarians performing the traditional functions, such as reference, acquisitions, and cataloging, are accompanied by specialists in such areas as systems management and operations research. This expansion of functions, along with the technological impact on more traditional functions, results in greater demands placed on library schools. Schools with limited resources and faculties are hard-pressed to educate students to meet the libraries' needs.

Battin states that research libraries are unique entities, with missions and staffs that are separate from those of other types of libraries, and that individuals should be educated for positions in such an environment. She suggests that the research libraries themselves take the responsibility for providing this education, formulating programs of study that incorporate the talents of many academic units on campus (including library schools, when possible). ${ }^{30}$ She claims that this might eliminate what she sees as the flaw in library education of overspecialization, which she describes thusly:

Our educational programs for academic librarianship have continued to stress an individualistic bias-the concept of the autonomous professional-and have actively procreated and encouraged the development of narrow specialists, either in academic subject disciplines or within the library profession. ${ }^{31}$

Battin's remarks are based on the assumption that, for years, libraries have been attempting to emulate the organizational structures of the academic units on the campus. She envisions a unique and fluid structure in research libraries in which librarians are able to see big pictures rather than just narrow details. In fact, organizational structure does play an important role in the functioning of the library. The structure essentially defines (however inexactly or vaguely) the duties to be performed by the individuals within the organization and, hence, can affect the education needed by the individuals. To examine the organizational structure of the library, one must first look at the structure of its environment-the college or university.

Cohen and March describe the university as being an "organized anarchy," exhibiting the following properties:

1. Problematic goals. It is difficult to impute a set of goals to the organization that satisfies the standard requirements of theories of choice. The organization appears to operate on a variety of inconsistent and ill-defined preferences. It can be described better as a loose collection of changing ideas than as a coherent structure. It discovers preferences through action more often than it acts on the basis of preferences.

2. Unclear technology. Although the organization manages to survive and (where relevant) produce, it does not understand its own proce- 
dures, the residue of learning from the accidents of past experiences, imitation, and inventions born of necessity.

3. Fluid participation. The participants in the organization vary among themselves in the amount of time and effort they devote to the organization; individual participants vary from one time to another. As a result, standard theories of power and choice seem to be inadequate; and the boundaries of the organization appear to be uncertain and changing. ${ }^{32}$

The library as an organization also exhibits these properties. If one dissects the library's organization, though, focusing on the two units that form the traditional bifurcated structure, one observes some anomalous occurrences. The public services, particularly the reference function, tend to adhere to the Cohen and March model, primarily because the activity simulates that of other units of the university. The technical services, however, while not having a purely bureaucratic structure, are more bureaucratic than the public services. They also tend to have more well defined goals and a clearer technology designed to achieve those goals. The lines separating the two functions are not clear, so the technical services do not have a completely distinct organizational structure. The distinctions that do exist affect the functional specializations within the library and, by implication at any rate, the education of the librarians. The goals and technology peculiar to the technical services must be incorporated simultaneously with an understanding of the structure and purposes of the library as a whole.

To further complicate matters, many libraries, particularly large ones, do not have a simple bifurcated structure. For instance, collection development may constitute a separate structural entity-one that shares some properties of both technical services and public services. On some campuses, special collections may be organized as a subunit. In addition to these, libraries may also have staff specialists who function apart from any of the substructures but who probably have a high level of interaction with all facets of the organization. These variances in functional specialization can result in pressure on library schools to educate for many types of positions. While all library schools should offer a strong and complete basic program of instruction, perhaps not all are able to provide specialization in areas hinted at above. It should be noted, though, that education in such areas is important to academic librarianship and those schools attempting to educate students for positions in academic libraries will have to be aware of the functions of those libraries and focus their programs accordingly.

Robert Muller suggests that the educational structure allows for more complex specializations among library schools, with some schools focusing attention on academic librarianship. ${ }^{33}$ Such a prospect may be tempting, but there are some inherent drawbacks. First of all, Muller's suggestion assumes a high degree of initial commitment that may not exist among students. It may be only after some exposure to a program that an individual student makes a decision regarding a career choice. Some students might find themselves having to transfer to another school in order to receive the specialized education. If Muller's model were followed, there would be, of necessity, a small number of schools specializing in academic librarianship. The students would have very limited, if any, interaction with students and faculty interested in other areas of librarianship. The small number of schools might also perpetuate certain views and methods; thus producing the danger of a stagnant environment in libraries. This revision would also involve great costs. Some institutions would incur enormous expenses in establishing the specialized programs, and others might experience such a loss of students that they would be forced to close their library schools (which, some might argue, would be a good thing).

While the traditional subject and functional specializations still exist and will probably continue to exist, a change in the vision of the library that first surfaced several years ago may produce fundamental alterations. The library, in fact the organization and dissemination of knowledge, is seen more and more frequently as a sys- 
tem rather than as disparate parts. The alteration of vision accompanies the proliferation of automation of library processes. This becomes especially evident when dealing with integrated systems of automation, but any automation process that affects library operations requires planning for the entirety of the organization. Such a change in thinking will affect library education. It could define an approach to education that is quite different from that of traditional programs. At present (and for the last several years), it seems that library education (at some institutions, at any rate) is in the midst of attempting a response to this phenomenon by adding the study of systems analysis to course content and by emphasizing a systems approach to library functions.

In summary, education for academic librarianship has a history of focus on technical training (not unlike library education in general). The most basic hindrance to the development of more appropriate education, rather than training, has been a lack of consensus on the role of the librarian in the academic community. This sometimes is obscured in the course of debates over such matters as the necessity for graduate education in subject areas. While such training may be essential to some positions in some libraries (subject specialists, for instance), it may not be de rigueur for everyone. What is needed is the revision of library school programs so that they offer graduate education, which includes the availability of detailed functional specialization, the opportunity for in-depth study of the intellectual and practical bases of academic libraries and their environment, and the incorporation of a systems approach to the organization, dissemination, and interpretation of knowledge.

At present, it does not appear that this revision can be accomplished in the traditional programs entailing approximately thirty-six semester hours of course work. So much of the program of study is introductory that there is little time to receive the depth of education needed to function in an academic library as a member of the scholarly community. While it may be ar- gued that the introductory content should be taught at the undergraduate level, the derivative nature of the discipline and the fact that many individuals enter the field relatively late in life are countervailing forces to the argument.

Additionally, programs should require students to conduct and report research in the form of theses or major research papers. Academic librarians are continually called upon to assist in the research process and may be required to conduct research in order to advance in the organization. Academic librarians also must be able to comprehend the research of others and to incorporate it locally, if feasible and desirable. Firsthand knowledge of the research process is not only helpful, it is essential in academe.

Few would argue with the belief that the academic world is different from other segments of society. Its activities and behavior are unique. The academic library exists to provide a variety of services (to aid research and teaching) to the community of students and scholars. The nature of this academic community, regardless of its size, effectively defines the backgrounds of its members. Academic librarians, as both members of the community and facilitators of the work of the community, should be prepared for the roles they are expected to assume. This preparation is different in kind (incorporating the research and curricular interests mentioned above) and, very likely, in duration as well. Service to the academic community necessitates understanding of the many facets of the community-understanding that might be fostered by both interdisciplinary study and extended study of the library and librarian in such an environment. An extended program may not be the proper course for librarians in all types of libraries (although convincing arguments have been made for an extended degree program educating all prospective librarians), but it seems to be ineluctable for academic librarians. If the extended program is adopted for the educating of academic librarians, it seems that the degree received should be an academic degree rather than a professional one (espe- 
cially if the requirement of a research paper is added, along with other such requirements). Of course, if the move to an extended program for all of library education is adopted, the academic degree and its requirement should be uniform. Impe- tus for change must come from within the schools, and it must include an understanding of the nature of the academic library and the role of the librarian in the environment of academe.

\section{REFERENCES}

1. O. Lee Shiflett, in Origins of American Academic Librarianship (Norwood, N.J.: Ablex, 1981), p. 210-11, notes that Dewey's efforts were aimed at the public library movement and that, while many academic librarians were aware of the inappropriateness of this model for them, the early years of library education exhibit a lack of concern for academic librarianship.

2. A. N. Whitehead, The Aim of Education and Other Essays (1929; reprint, New York: Macmillan, 1959), p.139.

3. Beverly Toy, "An Apt Summary," Journal of Academic Librarianship 2: 279 (Jan. 1977).

4. Charles C. Williamson, Training for Library Service (New York: D. B. Updike, 1923), p.4.

5. Association of American Universities, Journal of Proceedings and Addresses of the Annual Conference, V.26 (Chicago: AAU 1924), p.26. The AAU reiterated their recommendations in their 1927 report, but again it was all but ignored.

6. Ralph Munn, Conditions and Trends in Education for Librarians (New York: Carnegie Corp., 1936), p.12-13.

7. Louis Round Wilson, "Historical Development of Education for Librarianship in the United States," in Bernard Berelson, ed., Education for Librarianship (Chicago: American Library Assn., 1949) p.58-59.

8. Ralph W. Conant, The Conant Report: A Study of the Education of Librarians (Cambridge, Mass.: MIT Press, 1980), p.194.

9. Edward G. Holley, "Extended Library Education Programs in the United States," in Advances in Librarianship, V.11 (New York: Academic Press, 1981), p.51-76.

10. Barbara M. Robinson, "Librarianship under Attack," Library Journal 108: 348 (Feb. 15, 1983).

11. Peter F. Drucker, "Managing the Public Service Institution," College \& Research Libraries 37: 10 (Jan. 1976).

12. Pierce Butler, "Librarianship as a Profession," Library Quarterly 41: 240-41 (Oct. 1951).

13. Conant, The Conant Report, p.127.

14. Ibid., p.128.

15. Robert Muller, "Critique on University Library Education," Drexel Library Quarterly 3: 204 (Apr. 1967); Lewis A. Kenney, Letter to the Editor, College \& Research Libraries News no.7: 214 (July/Aug. 1975).

16. Edward G. Holley, "The Librarian Speaks: What the Modern Library Expects of the New Graduate," Southeastern Librarian 20: 227-28 (Winter 1970).

17. H. William Axford, "The Three Faces of Eve; or, The Identity of Academic Librarianship: A Symposium," Journal of Academic Librarianship 2: 276 (Jan. 1977).

18. Lester Asheim, The Core of Education for Librarianship (Chicago: American Library Assn., 1954).

19. Jesse H. Shera, The Foundations of Education for Librarianship (New York: Becker and Hayes, 1972), p.396.

20. Lester Asheim, "Education of Future Academic Librarians," in Herbert Poole, ed., Academic Libraries by the Year 200: Essays Honoring Jerrold Orne (New York: Bowker, 1977), p.137. The influence of Butler on Asheim's recommendation is obvious.

21. Robert B. Downs, "Are College and University Librarians Academic?" College \& Research Libraries 15: 14 (Jan. 1954).

22. Shera, The Foundations of Education, p.197.

23. "Standards for College Libraries," College \& Research Libraries 20: 276 (July 1959).

24. W. A. Moffett, "The Academic Job Crisis: A Unique Opportunity, or Business as Usual?" College E Research Libraries 34:193 (May 1973).

25. Joe Rader, "The Second Master's-Some Personal Views," Tennessee Librarian 30: 29 (Fall 1978).

26. Lawrence Clark Powell, "Education for Academic Librarianship," in Bernard Berelson, ed., Edu- 
cation for Librarianship (Chicago: American Library Assn., 1949), p.137.

27. Margaret Myers, "Library Personnel: Supply and Demand," Drexel Library Quarterly 17: 109 (Summer 1981).

28. Patricia Battin, "Developing University and Research Library Professionals: A Director's Perspective," American Libraries 14: 22 (Jan. 1983).

29. Ibid., p.23.

30. Ibid., p.24-25.

31. Ibid., p.24.

32. Michael D. Cohen and James G. March, Leadership and Ambiguity (New York: McGraw-Hill, 1974), p.2-3.

33. Muller, "Critique on University Library Education," p.206. 